2011s-42

\title{
The Twelve Principles of Incentive Pay
}

\author{
Marcel Boyer
}

\begin{tabular}{c}
\hline Série Scientifique \\
Scientific Series
\end{tabular}

Montréal

Avril 2011

(C) 2011 Marcel Boyer. Tous droits réservés. All rights reserved. Reproduction partielle permise avec citation du document source, incluant la notice (C).

Short sections may be quoted without explicit permission, if full credit, including (C) notice, is given to the source.
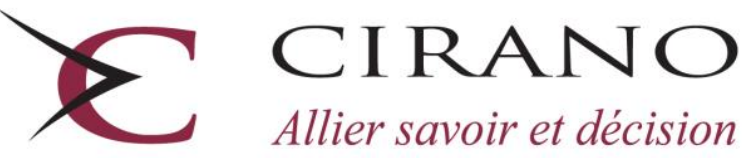

Allier savoir et décision

Centre interuniversitaire de recherche en analyse des organisations 


\section{CIRANO}

Le CIRANO est un organisme sans but lucratif constitué en vertu de la Loi des compagnies du Québec. Le financement de son infrastructure et de ses activités de recherche provient des cotisations de ses organisations-membres, d'une subvention d'infrastructure du Ministère du Développement économique et régional et de la Recherche, de même que des subventions et mandats obtenus par ses équipes de recherche.

CIRANO is a private non-profit organization incorporated under the Québec Companies Act. Its infrastructure and research activities are funded through fees paid by member organizations, an infrastructure grant from the Ministère du Développement économique et régional et de la Recherche, and grants and research mandates obtained by its research teams.

\section{Les partenaires du CIRANO}

Partenaire majeur

Ministère du Développement économique, de l'Innovation et de l'Exportation

\section{Partenaires corporatifs}

Banque de développement du Canada

Banque du Canada

Banque Laurentienne du Canada

Banque Nationale du Canada

Banque Royale du Canada

Banque Scotia

Bell Canada

BMO Groupe financier

Caisse de dépôt et placement du Québec

Fédération des caisses Desjardins du Québec

Financière Sun Life, Québec

Gaz Métro

Hydro-Québec

Industrie Canada

Investissements PSP

Ministère des Finances du Québec

Power Corporation du Canada

Raymond Chabot Grant Thornton

Rio Tinto

State Street Global Advisors

Transat A.T.

Ville de Montréal

\section{Partenaires universitaires}

École Polytechnique de Montréal

HEC Montréal

McGill University

Université Concordia

Université de Montréal

Université de Sherbrooke

Université du Québec

Université du Québec à Montréal

Université Laval

Le CIRANO collabore avec de nombreux centres et chaires de recherche universitaires dont on peut consulter la liste sur son site web.

Les cahiers de la série scientifique (CS) visent à rendre accessibles des résultats de recherche effectuée au CIRANO afin de susciter échanges et commentaires. Ces cahiers sont écrits dans le style des publications scientifiques. Les idées et les opinions émises sont sous l'unique responsabilité des auteurs et ne représentent pas nécessairement les positions du CIRANO ou de ses partenaires.

This paper presents research carried out at CIRANO and aims at encouraging discussion and comment. The observations and viewpoints expressed are the sole responsibility of the authors. They do not necessarily represent positions of CIRANO or its partners. 


\title{
The Twelve Principles of Incentive Pay ${ }^{*}$
}

\author{
Marcel Boyer
}

\section{Résumé / Abstract}

Les mécanismes d'incitation utilisés dans l'industrie des services financiers en particulier, mais aussi dans de nombreux autres contextes, reconnaissent les revenus générés presque indépendamment des risques, menant à la négligence des risques et donc à une prise injustifiée risques. Plusieurs économistes ont mis en garde les entreprises financières, industrielles et de services contre ces pratiques, leur rappelant l'importance de bien considérer la prise de risque pour éviter ce que les économistes et les assureurs appellent «l'aléa moral ». Je passe en revue la rémunération incitative basée sur les premiers principes de l'économie des organisations. De toute évidence, dans de nombreux cas, ces principes n'ont pas été suivis, ce qui a conduit à une crise de gouvernance, une crise financière et une crise économique.

Mots clés : mécanismes d'incitation, risque, rémunération incitative.

The incentive mechanisms used in the financial services industry in particular, but also in many other contexts, reward income generated almost regardless of risk, with negligent and faulty risk measurement and unjustified risk taking as predictable results. A number of economists warned financial, industrial and service corporations against these practices, reminding them that, in designing incentive mechanisms, it is necessary to take account of the risks taken or incurred to avoid what economists and insurers call "moral hazard." I review incentive pay based on first principles of the economics of organization. Clearly, in many cases, those principles were not followed, which led to a governance crisis, a financial crisis and an economic crisis.

Keywords: Incentive mechanisms, risk, incentive pay.

\footnotetext{
* I would like to thank Marie Claire Villeval of Université Lumière Lyon 2 who made the completion of this paper possible. Her advice and patience are gratefully acknowledged. I am also indebted to the participants in the AFSE session on incentive pay (Journées de l'économie, Lyon, November 2009) for their comments, in particular Augustin Landier, Pierre Alain Muet, and Philippe Askenazy. Needless to say, I remain solely responsible for the content of this paper.

${ }^{\dagger}$ Bell Canada Emeritus Professor of Economics, Université de Montréal, Research Fellow, Department of Economics, École Polytechnique de Paris, University Affiliate and External Expert, Analysis Group, Fellow of CIRANO, CIREQ and the C.D. Howe Institute. marcel.boyer@cirano.qc.ca.
} 


\section{INTRODUCTION}

In general, incentive pay is not desirable.

It is not desirable for two main reasons. First, it puts the worker or employee at risk of fluctuations in his/her wages, salaries, and other benefits. Given that human beings are known to prefer certainty outcomes over risky ones, the risk level faced by the individual will need to be properly or competitively compensated, in such a way that the expected compensation (probability-weighted mean compensation) will increase with the level of risk so supported. Second, an incentive compensation system is costly to run. It is not easy to properly calibrate the intensity of incentives a compensation system should implement, as the twelve principles discussed in this paper will suggest. Moreover, a fluctuating compensation may generate resentment if and when compensation falls below the mean level, a situation which is likely to occur about no less than half of the time.

There are different reasons to revisit hic et nunc the topic of incentive pay. First, there is strong criticism of actual systems in the context of the recent economic recession, which allegedly stemmed in part from exaggerations in the mortgage market in the US as well as, for many observers and commentators, from the structure of incentive pay systems in place in the financial sector. Second, we see in these troubled times movements away for incentive or variable pay in some sectors but toward such systems in most other sectors. Third, there are clear misunderstandings of the basic issues related to the role and nature of incentive pay in general.

In the wake of the recent financial crisis, large brokerage firms and investment banks paid out record bonuses to their managers, the very people who had put them in serious trouble. According to New York state's comptroller's office, Wall Street firms paid \$33.2 billion in bonuses in 2007, about the same amount as in 2006, while the shareholder value of the seven biggest firms fell by more than $\$ 200$ billion. For example: Lehman Brothers raised its bonuses by $10 \%$ in 2007 , bringing them to $\$ 5.7$ billion, and was 
bankrupt in September 2008. What if these bonuses were among the causes of the financial crisis? The incentive mechanisms used in the financial services industry in particular reward income generated almost regardless of risk, with negligent and faulty risk measurement and unjustified risk taking as predictable results. A number of economists warned financial, industrial and service corporations against these practices, reminding them that, in designing incentive mechanisms, it is necessary to take account of the risks taken or incurred to avoid what economists and insurers call "moral hazard."

Economists specializing in performance incentives have been suggesting for a number of years that bonuses be made conditional on risk audits to penalize, rather than reward, exceptional financial results relying on reckless risk-taking. ${ }^{1}$ These suggestions have been mostly ignored with disastrous effects. But there seems to be light at the end of the tunnel. In the rescue of Fannie Mae and Freddie Mac, the managers, shareholders and bondholders of these government-sponsored enterprises, which were overly dominant in mortgage credit and were protected by indulgent regulators, have taken a beating. The government will be paid back first. And these companies can no longer benefit from their political relationships to hide mismanagement: the door is closing! While the horse may be gone, at least the colt will be kept in the stable.

According to one analyst, banks have replaced their traditional "originate and hold" model with a new "originate and transfer" model under which they lend and then sell the debt to someone else. ${ }^{2}$ The more widespread adoption of this new model may be a factor responsible for the crisis. However, the phenomenon of securitization is not new: banks have been following this practice for nearly 30 years without causing crises. What has changed in the last decade was the significant growth in securities backed by subprime mortgages which were traded (transferred) so fast and so often that a major problem of transparency ends up arising. This practice led to the creation of a class of capital around which it becomes enormously difficult to establish who is assuming fundamental risks.

\footnotetext{
${ }^{1}$ See Bernard Sinclair-Desgagné, "How to restore higher-powered incentives in multitask agencies," Journal of Law, Economics, \& Organization, Vol. 15, Issue 2 (July 1999), pp. 418-433.

2 Paul Mizen, "The Credit Crunch of 2007-2008: A Discussion of the Background, Market Reactions, and Policy Responses,” Federal Reserve Bank of St. Louis Review, September/October 2008, pp. 531-568.
} 
This particularity has distorted incentives in many different ways. Mortgage brokers' fees were based solely on the number of mortgage loans provided, without the risk of default taken into consideration. Brokers thus had no incentive at all to look into the risks linked to subprime mortgage loans. On the contrary, they had incentives to provide the greater possible number of mortgage loans regardless of the risk level they presented. Lenders had no incentive to check the quality of the mortgage loans granted, given that they intended to bundle and resell these assets in the form of complex derivatives. In the years before the crisis broke out, these institutions increased their subprime mortgage loan offerings, reselling them to investors looking for higher (but riskier) returns. Banks, investment banks and other financial institutions were quick to rely on choices made by their competitors or partners while assuming that those competitors and partners must have checked the risk quality and characteristics of such securities, hence dispensed of making "redundant" costly verifications, a well known free riding problem. In the end, a global web of individually rational actions and policies based on others' individually rational actions and policies, each other ones relying on each other ones, ended up creating a huge systemic risk which by definition cannot always be avoided: eventually, the chips must fall!

Incentive pay may be explained and justified by and in reference to four factors or phenomena, which may have important effects on the net benefits of an organization and which are often although not always present in practice:

- moral hazard, defined as the tendency of individuals to alter their safety, effort or initiative behaviour, as private information becomes available to them, if they are protected or insured against the losses otherwise incurred following unfavourable events or unable to capture part of the benefits generated by such behaviour, thereby increasing the probability of unfavourable events and/or reducing the probability of favourable ones;

- adverse selection, defined as the tendency of individuals to use strategically their private information to pursue objectives that are non congruent with those of the organization, including accepting jobs and responsibilities for which they may not 
be sufficiently competent or productive, a characteristic better known to them that to the organization hiring them;

- the need to induce profitable cooperation in organizations, broadly defined to include team work as well as contractual relations between business partners and between stakeholders;

- the need to counteract costly or unproductive institutional and/or regulatory constraints.

The first two factors/phenomena represent the traditional bases for incentive pay. There is moral hazard when the effort exerted by an agent to raise the probability of success, the quality, the productivity, or the profitability of some projects cannot be observed by other parties or stakeholders, and is, therefore, private information of the agent. This information can be used strategically either to reduce costly effort levels or to redirect such effort towards other objectives. A firm or a collection of citizens for whom the production or distribution of private goods and services or public and social goods and services is intended and done, or their representatives, may not be able to observe the effort levels exerted by the providers of those goods and services to make this provision as close as possible to its expected quality, quality/cost ratio, and other characteristics.

There is adverse selection each time an agent can benefit and abuse of an informational advantage on some relevant characteristics. This asymmetry of information reduces the efficiency of contracting since both parties are not in full knowledge of the relevant facts. Adverse selection is a pre-contractual problem of opportunism, while moral hazard is a post-contractual problem of opportunism. Other similar problems of asymmetric information leading to some opportunism by one or both parties to a contract exist, such as free-riding behaviour and hold-up behaviour. Efficient contracting in the production or distribution of private goods and services or public and social goods and services must include incentive-compatible clauses that are intended to optimally reduce the impact of such potential sources of inefficiency. 
Moral hazard and adverse selection may come in different forms and shapes, in static and dynamic contexts. Boyer and Robert $(2006)^{3}$ for instance develop a model to explain the level of inertia as an endogenous rational choice made by the organization (principal). They show that the efficient organizational response to the presence of private information on the value of change will in general be to bias the decision rule towards the status quo, that the compensation of the agent differs significantly according to whether the information is private to the principal or the agent, and that the efficient distribution of 'real' authority in an organization need not always be profitably retained by the principal.

The third may or may not have an incentive basis: it does [not] if the worker or service provider can [cannot] make decisions capable of mitigating the risk present in the relation between the worker/provider and the employer/client. More generally, the design of incentive pay, price, and contract systems in value chains and value networks represents major challenges for firms and organizations in complex production and delivery systems. Outsourcing, offshoring and public-private partnerships are examples of complex production and delivery systems, where risks and asymmetric information are significant characteristics. Although important, these concerns address inter firm relationships and we will not pursue their analysis here. ${ }^{4}$

The fourth reason is of a different nature. Even if there is no moral hazard, no adverse selection, and no need or willingness to share risks, a firm may find it profitable to implement an incentive compensation system if regulatory constraints prevent it from disciplining the worker or manager who fails to meet expectations, the required output, or

\footnotetext{
${ }^{3}$ Boyer, M. and J. Robert, "Organizational Inertia and Dynamic Incentives", Journal of Economic Behavior and Organization 59(3), March 2006, 324-348. See also in the same vein Holmström, B., "On teh Theory of Delegation," chapter 8 in M. Boyer and R.E. Kihlstrom (eds.), Bayesian Models in Economic Theory, Studies in Bayesian Econometrics, North-Holland Elsevier Science Pub., 2004.

${ }^{4}$ See Boyer, M., "The Design of an Efficient Offshoring Strategy: Some Reflections with Links to SNCLavalin." Chapter 7 in Proceedings of the conference "Offshoring Outsourcing: Capitalizing on Lessons Learned," (October 2006), edited by Daniel Trefler. Conference sponsored by Industry Canada and the Rotman School of Management. Available from: http://www.rotman.utoronto.ca/offshoring/, 2009, 50 pages.
} 
the labour agreement in general. In such case, incentive pay makes misbehaviour costly for the protected worker/manager himself, hence contributes to reducing misbehaviour.

Incentive pay systems should be distinguished from risk sharing contracts. Even if the worker/provider cannot influence the probability of different states or the results in those different states, a risk sharing agreement may be of interest as it makes the worker/provider and the employer/client partners (although with different levels of responsibility and control) in the relevant business. Hence variable pay may be designed as a risk sharing agreement. But a variable pay system need not be an incentive pay system. ${ }^{5}$

The above suggests that, unless there is a major observation or information problem or significant institutional or regulatory constraints, there is no case for incentive compensation. The above suggests also that there are dangers for an organization not to have an incentive pay system. Indeed, the compensation formula(s) in any organization is a fundamental management tool to achieve coordination between the efforts and decisions of different individuals and divisions towards achieving the highest possible level of performance, measured with respect to the overall objectives and mission of the organization. The failure to realize the importance of this tool could jeopardize the organization's capability to fulfill its mission, as incentive pay is the most efficient way to make the key members of the organization liable or responsible for their own relative contributions to the success or lack of success of the organization. In so doing, it could protect the organization against failing employees as well as protect successful employees against being held up by their employer organization. Finally, putting in place an incentive compensation system forces the organization to explicitly and concretely state its mission and objectives.

\footnotetext{
${ }^{5}$ Risk sharing agreements are quite common for instance in intellectual property compensation contracts as well as in patent pooling agreements. See Boyer, M., "The Canadian Copyright Board: Economic Concepts and Principles in Decisions and Arguments", Proceedings of the ALAI Conference (Ottawa 2009-12-02) "Copyright Board of Canada: Bridging Law and Economics for 20 years ", Montréal, Editions Carswell/Yvon Blais, 2011 (forthcoming).
} 
Incentive pay should be understood as compensation schemes which create congruence within an organization: incentive pay can contribute to ensuring that the pursuit of individual objectives or interests is canalized towards the achievement of the organization's goals and objectives.

The currently designed compensation formulas may not be the best or optimal ones to achieve the goals set for the organization: hence the current twelve main or basic principles. It is important that the formula be transparent, explicit, and optimally designed given the characteristics of the job to be done and the mission or objectives of the organization. Many incentive pay systems remain opaque and poorly designed, a phenomenon which contributes to the ill-famed use of variable compensation in numerous organizations.

\section{THE PSYCHOLOGY AND ECONOMICS OF INCENTIVE PAY}

Why and when are incentive pay systems necessary or desirable? The answer to this question relies on three main phenomenal pillars: the typical individual preference of certainty over risk goes against incentive pay and therefore, an incentive pay system should be justified by strong reasons showing the necessity and profitability of implementing such a system; the individuals' characteristics and effort, which are linked to the organization's performance, may be difficult to observe in many contexts, preventing contracts to be written on the basis of such characteristics and effort; the links in question involve the (imperfectly observed and evaluated) impacts of the employees' or stakeholders' (unobserved) real decisions and/or actions on the organization's performance.

What do we need to study such a question? First, a behaviour model, that is a formalization of individual behaviour amenable to useful sensitivity analysis in order to derive some general principles to follow in setting up and managing an incentive pay system. We will use here a first principles economic model: an individual's behaviour can be explained and predicted from two sets of variables, namely preferences and 
incentives. In this model, preferences are a relatively stable long run phenomenon, either deeply rooted in innate behavioural characteristics or determined through long term personality-defining socialization, while incentives can be modified to curb the individual's behaviour. Both preferences and incentives may change but on different time scales: for incentive pay consideration, only the first set of variables is considered to be constant or fixed and therefore changes in behaviour can only be obtained through changes in the second set of variables.

Second, we need a formal representation of an organization, possibly simplified to its bare bone skeleton. Again, we will use a first principles representation of an organization: one principal and one agent whose interactions determine the organization's performance. The head or "principal" (manager, supervisor, chairperson) of the organization, assumed to be risk-neutral, wants to maximize the expected surplus of the organization over the different "states of the world", which are the different situations or contexts in which the organization and its members may find themselves. The principal asks the agent (manager, worker, team, division) to perform tasks that are of interest for the organization. A surplus is generated for the benefit of the principal and the agent. Third, we need to identify explicitly the set of constraints that an incentive pay system must satisfy: informational constraints, behavioural constraints, and legal constraints such as those imposed by limited liability, contract law, tort law, vicarious liability, etc. ${ }^{6}$

Let us be a bit more precise. In each given state $i$ occurring with probability $p_{i}$, the surplus is by assumption equal to the total value $\Pi_{i}$ of the organization minus the agent's compensation, which may depend on the realized state, that is, based on the organization's overall performance $W_{i}=W\left(\Pi_{i}\right)$ :

$$
\max E[\Pi-W(\Pi)]=\sum_{i} p_{i}\left(\Pi_{i}-W_{i}\right)
$$

\footnotetext{
${ }^{6}$ There is an abundant literature in economics on those topics. Two seminal works can be mentioned here: Paul Milgrom and John Roberts, Economics, Organizations and Management, Prentice-Hall, 1992; JeanJacques Laffont and David Martimort, The Theory of Incentives: The Principal-Agent Model, Princeton University Press, 2001.
} 
The agent or individual, assumed to be risk-averse, wants to maximize his own well being equal to the expected value of his "utility" or satisfaction, which is a function of his remuneration $U\left(W_{i}\right)$, increasing with $W_{i}$ but at a decreasing rate $\left(U^{\prime}>0, U^{\prime \prime}<0\right)$ :

$$
\max E\left[U\left(W_{i}\left(\Pi_{i}\right)\right]=\sum_{i} p_{i} U\left(W_{i}\right)\right.
$$

Let us assume first that there is imperfect but complete information, that is, the state of the world is unknown at the time the decisions are made but both the principal and the agent have the same knowledge, that is, in particular, both the characteristics and the efforts of the agent are observed by both. The optimal remuneration scheme is the one which maximizes the expected or probability-weighted average surplus of the organization subject to the constraint that the agent (or sufficiently many individuals) accepts to participate, that is, accepts the organization's conditions of employment. The optimal remuneration scheme solves:

$$
\begin{aligned}
& \max E[\Pi-W]=\sum_{i} p_{i}\left(\Pi_{i}-W_{i}\right) \\
& \text { subject to } \sum_{i} p_{i} U\left(W_{i}\right) \geq U_{0}
\end{aligned}
$$

\section{THE TWELVE PRINCIPLES OF INCENTIVE PAY}

Let us form the Lagrangian $L$ or problem (3):

$$
L=\sum_{i} p_{i}\left(\Pi_{i}-W_{i}\right)+\lambda\left(\sum_{i} p_{i} U\left(W_{i}\right)-U_{0}\right)
$$

Necessary conditions for a maximum of $L$ are that for each state $i$ :

$$
\frac{\partial L}{\partial W_{i}}=-p_{i}+\lambda p_{i} U^{\prime}\left(W_{i}\right)=0
$$

and therefore

$$
U^{\prime}\left(W_{i}\right)=\frac{1}{\lambda}
$$

which implies that $W_{i}$ is constant across different states $i$. Hence: 


\section{Given that the individual is risk averse, it is efficient for the organization to set up, under imperfect but complete information, a state-independent compensation scheme [no incentive pay].}

Suppose, without loss of generality, that there are two possible states of the world, state 1 and state 2 with performance levels $\Pi_{1}$ and $\Pi_{2}$ respectively with $\Pi_{1}<\Pi_{2}$; suppose that if the individual's effort is high, the probability of state 2 , the high performance state, is $x$ and if effort is low, that probability is $y$ with $x>y$. Moreover, let us suppose that the individual's effort is costly to him and that the cost in money terms of the high level of effort is $\phi$ while the cost of the low level of effort is 0 . Let us suppose that if she could observe the level of effort, the head of the organization would prefer a high level of effort from the individual at a cost of $W_{0}+\phi$ to a low level of effort at a cost of $W_{0}$, that is:

$$
x \Pi_{2}+(1-x) \Pi_{1}-\left(W_{0}+\phi\right)>y \Pi_{2}+(1-y) \Pi_{1}-W_{0} .
$$

If the level of effort is (perfectly) observed by the head of the organization, then she would simply compensate appropriately the individual for the effort she asks for but still apply the principle of insurance: remuneration is independent of the state $i$ :

$$
W_{1}=W_{2}=W_{0}+\phi
$$

But if effort is an important driver of performance and if the individual's effort is not observable by the principal, the individual must be made responsible enough for the performance of the organization to induce him to exert the proper level of effort. To achieve that, a link must be created between the level of remuneration of the agent and the level of performance of the organization, thereby submitting the individual to some level of risk (uncertain pay) and relaxing the principle of insurance. This moral hazard situation may call for the individual to become subject to some exposure to risk in his remuneration.

Without an incentive pay system, the individual is facing the following choice: provide at a cost of $\phi$ the high level of effort, which in any case will not be observed, or provide the minimal level 0 , but in both cases get the same remuneration, that is, compare

$$
E_{x} U(W)=x U(W-\phi)+(1-x) U(W-\phi)=U(W-\phi)
$$


with

$$
E_{y} U(W)=y U(W)+(1-y) U(W)=U(W)
$$

Clearly, since $U(W)>U(W-\phi)$, the individual chooses the second alternative with the minimal level of effort.

\#2 - THE PRINCIPLE OF RATIONALITY

When the effort is not observable and the compensation is independent of the realized state of the world, that is, independent of the organization's performance, the individual will provide a suboptimal level of effort (the individual cost-minimizing level of effort).

To induce a high level of effort from the individual, the principal must set up an incentive remuneration scheme so that the individual will find it in his best interest to provide the high effort level that she wants him to provide. Two constraints must then be met by the remuneration scheme: a participation constraint (the organization must convince the individual to enter and participate in the organization, given his best alternative employment opportunity represented by $U_{0}$ ), that is, under he high level of effort,

$$
x U\left(W_{2}-\phi\right)+(1-x) U\left(W_{1}-\phi\right) \geq U_{0},
$$

and an incentive compatibility constraint (the individual must choose voluntarily, since effort is not observed anyway, the high level of effort), that is:

$$
x U\left(W_{2}-\phi\right)+(1-x) U\left(W_{1}-\phi\right) \geq y U\left(W_{2}\right)+(1-y) U\left(W_{1}\right) .
$$

Clearly, as $x>y$, we need $W_{2}>W_{1}$ and therefore the principle of insurance is relaxed.

The head of the organization will choose the remuneration scheme $\left(W_{1}, W_{2}\right)$ which maximizes the expected performance of the organization net of the labour costs, subject to the participation constraint and the incentive compatibility constraint, that is, she will solve the following optimization problem:

$$
\begin{aligned}
& \max _{W_{1}, W_{2}} x\left(\Pi_{2}-W_{2}\right)+(1-x)\left(\Pi_{1}-W_{1}\right) \\
& \text { subject to (11) and (12). }
\end{aligned}
$$


Clearly, the head has no interest in paying more than necessary and so, the two constraints (11) and (12) will be satisfied with a strict equality in an efficient incentive pay system.

Given that the individual is risk averse $\left(U^{\prime \prime}(W)<0\right)$, the expected level of remuneration net of effort will be higher under an incentive pay system than under a constant pay system, that is

$$
x\left(W_{2}-\phi\right)+(1-x)\left(W_{1}-\phi\right)>W_{0} .
$$

The fact that he is exposed to a level of risk (uncertainty in his remuneration) under the incentive pay system requires that he be compensated for that risk so that his expected compensation is larger than his best alternative $\left(W_{0}\right)$, while properly compensating him for the level of effort $(\phi)$ he will be asked and induced to provide.

Let us now consider that the level of effort is a continuous variable $e \geq 0$ and that the cost of effort in monetary equivalent terms is $C(e)$. In the analysis above, the only variable the principal could observe was the level of performance of the organization. To make the analysis more realistic, let us assume that although effort is not observed as such, the head can observe two proxies, that is, two indicators: one directly related to effort, say $z=e+\varepsilon$, with $\varepsilon$ being a random variable representing all factors that blur the observation of effort $e$, and another indicator $v$ imperfectly related to $\varepsilon$ but not directly related to $e$.

This is typical of many applied cases: not only do we have an evaluation of the organization's performance but we also have different imperfect observations of the individual's effort: an imperfect observation of effort through a variable $z$, directly related to effort but blurred by random factors represented by $\varepsilon$, and an imperfect observation of type $v$, representing observables related to those random factors, that is affecting the quality or reliability of the observation of effort $e$ through variable $z$. Indicator variable $z$ may be either the performance of the organization itself (or depend in part on the performance of the organization), or comments of better informed colleagues on the 
individual's level of effort; or sales record; or satisfaction of surveyed clients; or a combination of the above. Indicator variable $v$ may be thought of as being related to the particular "conditions of realization" of an individual's task such as the general economic conditions, the industry performance average (benchmark), the recent introduction of substitute products, etc.

Indicator variable $z$ can be seen as providing information of the first order or directly related to effort while indicator variable $v$ can be seen as providing information of the second order or indirectly related to effort through making the relationship between effort and variable $z$ more precise or reliable. Rather than relating the individual's compensation to the sole performance $\Pi$ of the organization, the head can relate it to the observed indicator variables $z$ and $v$, which are by assumption more informative of the level of effort exerted by the individual. Suppose that she uses the following relatively general linear formula:

$$
W=\alpha+\beta(z+\gamma v)=\alpha+\beta(e+\varepsilon+\gamma v)
$$

where $\gamma$ is the weight carried by the indicator variable $v$ in the compensation formula, the weight of indicator variable $z$ being normalized to 1 .

The compensation formula is now composed of two parts: the first part, represented by the parameter $\alpha$, is the portion which is independent of the observed indicator proxies $z$ and $v$ and therefore independent of (unobservable) effort level $e$; the second part, represented by the expression $\beta(e+\varepsilon+\gamma v)$, is the portion indirectly dependent on effort through the effect of $e$ on the value of the random proxy $z$, given the proxy $v$, which serves to make the observation of $z$ more valuable, that is, more revealing of the probable value of $e$.

The parameter $\beta$ represents a measure of the "intensity of incentives" since it is the slope of the effort factor. It measures the importance of effort in determining the total compensation. The individual is facing a risk in his compensation since it will depend not only on his level of effort $e$ but also on the realization of the random variables $\varepsilon$ and $v$. 
We can define a certainty equivalent compensation $C E W$ in such a way that the individual would be indifferent, given the level of effort he is providing, between that fixed assured compensation level $C E W$ and the random compensation level affected by $\varepsilon$ and $v$. The certainty equivalent compensation is measured by the expected compensation $E W$ provided by the incentive compensation formula minus the cost to the individual of providing the chosen level of effort $C(e)$ and minus a risk premium $R$ equal to what the individual would be ready to pay to avoid that risk in his compensation. The risk premium is to a first approximation proportional to the risk level measured by the variance of the compensation $\operatorname{Var}(W)$, for a given level of effort, and to the level of risk aversion $r$ of the individual. More precisely, we have

$$
C E W=E W-C(e)-R=\alpha+\beta(e+\bar{\varepsilon}+\gamma \bar{v})-C(e)-\frac{1}{2} r \operatorname{Var}(W)
$$

with

$$
\operatorname{Var}(W)=\beta^{2} \operatorname{Var}(\varepsilon+\gamma v)=\beta^{2}\left(\operatorname{Var}(\varepsilon)+\gamma^{2} \operatorname{Var}(v)+2 \gamma \operatorname{COV}(\varepsilon, v)\right) .
$$

We obtain the following principle:

\section{\# 3 - THE PRINCIPLE OF CERTAINTY EQUIVALENCE}

The individual is indifferent between facing a risky compensation perspective and its certainty equivalent value equal to the expected compensation (net of the cost of effort) minus a risk premium, which compensates the individual for the risk he faces.

Given that the individual is facing the compensation formula (15) and given that effort represents a personal cost $C(e)$, he will choose to provide the level of effort which maximizes his expected utility. This is equivalent to maximizing the $C E W$ since that is the level of compensation which if obtained with certainty is equivalent in terms of utility to the risky compensation formula. Hence, the level of effort chosen by the individual may be characterized as maximizing $C E W$ and therefore is characterized by

$$
\beta-C^{\prime}(e)=0 \text {. }
$$

This expression is indeed an incentive compatibility constraint: if the head of the organization wants to induce the level of effort $\hat{e}$, then she must set $\beta$ equal to $C^{\prime}(\widehat{e})$, that is, equal to the individual's marginal cost of providing effort evaluated at $e=\widehat{e}$. The 
larger $\hat{e}$, the larger $\beta$ and the larger the individual's compensation. The value of $\alpha$ is then set to satisfy the participation constraint $C E W(e)=W_{0}$.

A compensation scheme may therefore be characterized by the triplet $(\alpha, \beta, \gamma)$. To any compensation scheme or triplet $(\alpha, \beta, \gamma)$, we can associate the organization's measure of profitability

$$
E \Pi(e)-\left(\alpha+\beta(e+\bar{\varepsilon}+\gamma \bar{v})-C(e)-\frac{1}{2} r \beta^{2}\left(\operatorname{Var}(\varepsilon)+\gamma^{2} \operatorname{Var}(v)+2 \gamma \operatorname{COV}(\varepsilon, v)\right) .\right.
$$

The head of the organization will choose $(e, \alpha, \beta, \gamma)$ to maximize this measure of profitability subject to the constraint $\beta=C^{\prime}(e)$, the value of $\alpha$ being set residually so that $C E W(e)=W_{0}$. The chosen (profitability maximizing) value of $\gamma$, that is, the weight to be given to proxy variable $v$ in the compensation formula, can be characterized by

$$
-\frac{1}{2} r\left(C^{\prime}(e)\right)^{2} \frac{\partial \operatorname{Var}(\varepsilon+\gamma \nu)}{\partial \gamma}=0
$$

that is

$$
\frac{\partial \operatorname{Var}(\varepsilon+\gamma v)}{\partial \gamma}=2 \gamma \operatorname{Var}(v)+2 \operatorname{COV}(\varepsilon, v)=0
$$

leading to

$$
\gamma^{*}=-\frac{\operatorname{COV}(\varepsilon, v)}{\operatorname{Var}(v)} .
$$

We obtain the following principle:

\section{\# 4 - THE PRINCIPLE OF DUAL PERFORMANCE MEASURES}

The relative weight assigned to the information of the second order in the evaluation process [the weight of the information of the first order being normalized to 1] is equal to the negative of its relative informativeness, measured by the ratio of its covariance with the random factors that blur the reliability of the information of the first order and its own variance. 
If $\operatorname{COV}(\varepsilon, v)>[<] 0$, then $\gamma$ is negative [positive], the more so the larger $\operatorname{COV}(\varepsilon, v)$ is in absolute value. The larger the variance $\operatorname{Var}(v)$, the less informative $v$ is and the closer $\gamma^{*}$ is to zero.

Substituting back into the risk premium, we obtain

$$
\begin{gathered}
R=\frac{1}{2} r \operatorname{Var}(W)=\frac{1}{2} r \beta^{2} \operatorname{Var}(\varepsilon+\gamma v)=\frac{1}{2} r \beta^{2}\left(\operatorname{Var}(\varepsilon)+\gamma^{2} \operatorname{Var}(v)+2 \gamma \operatorname{COV}(\varepsilon, v)\right) \\
=\frac{1}{2} r \beta^{2}\left(\operatorname{Var}(\varepsilon)-\frac{(\operatorname{COV}(\varepsilon, v))^{2}}{\operatorname{Var}(v)}\right)>0 .
\end{gathered}
$$

\section{\# 5 - THE PRINCIPLE OF THE RISK PREMIUM}

The risk premium the firm must pay to the individual when it implements an incentive (risky) pay system is

* increasing with the individual's risk aversion, the intensity of incentives, the imprecision of the information of the first order;

decreasing with the absolute value of the informativeness of the information of the second order.

The characterization of the profit maximizing value of $e$ can be achieved by first replacing $\beta$ by $C^{\prime}(e)$ and using $\gamma^{*}$ from (21) in the measure of profitability and then maximizing that measure with respect to $e$. We obtain from

$$
\max _{e} E \Pi_{i}(e)-\left(\alpha+C^{\prime}(e)(e+\bar{\varepsilon}+\gamma \bar{v})-C(e)-\frac{1}{2} r\left(C^{\prime}(e)\right)^{2}\left(\operatorname{Var}(\varepsilon)-\frac{(\operatorname{COV}(\varepsilon, v))^{2}}{\operatorname{Var}(v)}\right)\right)
$$

a characterization of the efficient level of effort to be induced from the individual (assuming without loss of generality that $\bar{\varepsilon}=\bar{v}=0$ ):

$$
E \Pi_{i}^{\prime}(e)-e C^{\prime \prime}(e)+r C^{\prime}(e) C^{\prime \prime}(e)\left(\operatorname{Var}(\varepsilon)-\frac{(\operatorname{COV}(\varepsilon, v))^{2}}{\operatorname{Var}(v)}\right)=0
$$

leading to the condition

$$
e^{*}=\frac{E \Pi_{i}^{\prime}\left(e^{*}\right)+r C^{\prime}\left(e^{*}\right) C^{\prime \prime}\left(e^{*}\right)\left(\operatorname{Var}(\varepsilon)-\frac{(\operatorname{COV}(\varepsilon, v))^{2}}{\operatorname{Var}(v)}\right)}{C^{\prime \prime}\left(e^{*}\right)},
$$


which defines the profitability maximizing level of effort $e^{*}$ to be induced from the agent. For example, assuming that $C(e)=c e^{2}$, we have $C^{\prime}(e)=2 c e$ and $C^{\prime \prime}(e)=2 c$. Hence, $e^{*}$ would be given (normalizing $c$ at 1 ) by

$$
e^{*}=\frac{1}{2}\left(\frac{E \Pi_{i}^{\prime}\left(e^{*}\right)}{1-2 r\left(\operatorname{Var}(\varepsilon)-\frac{(\operatorname{COV}(\varepsilon, v))^{2}}{\operatorname{Var}(v)}\right)}\right) .
$$

From (18), we then get

$$
\beta^{*}=\frac{E \Pi_{i}^{\prime}\left(e^{*}\right)}{1-2 r\left(\operatorname{Var}(\varepsilon)-\frac{(\operatorname{COV}(\varepsilon, v))^{2}}{\operatorname{Var}(v)}\right)}=\frac{E \Pi_{i}^{\prime}\left(e^{*}\right)}{1-2 r \operatorname{Var}(\varepsilon)+2 r \frac{(\operatorname{COV}(\varepsilon, v))^{2}}{\operatorname{Var}(v)}},
$$

that is, as expected, $\beta^{*}=2 e^{*}$. As for the value of $\alpha$, it is determined residually to satisfy the participation constraint. ${ }^{7}$ We obtain the following principles:

\# 6 - THE PRINCIPLE OF INTENSITY OF INCENTIVES

From (26), the intensity of incentives is

- increasing with the expected impact of the individual's effort on the performance of the organization, with the coefficient of risk aversion, and with the imprecision of the information of the first order (the evaluation measure)

- decreasing with the absolute value of the informativeness of the information of the second order

\# 7 - THE PRINCIPLE OF OPTIMIZED PERFORMANCE

An organization's performance will be lower, the level of effort demanded will be lower, and the intensity of incentives will be lower when the degree of risk aversion of its typical members is larger, the difficulty of monitoring or observing effort is higher, and the marginal cost of effort increases faster.

\footnotetext{
${ }^{7}$ Under full information, assuming $C(e)=e^{2}$, we would have $e^{*}=\frac{1}{2} E \Pi_{i}^{\prime}\left(e^{*}\right)$.
} 
The last two principles suggest that if the individual's effort is subject to decreasing returns, that is $\Pi_{i}^{\prime \prime}(e)<0$, then the efficient level of effort demanded from the individual will be lower, the more risk averse the individuals are, the more difficult the observation of effort is (measured by the variance $\operatorname{Var}(\varepsilon+\gamma v)$ ), and the faster the marginal cost of effort is increasing.

In other words, an organization's performance will increase if the organization hires individuals who are less risk averse and whose disutility of effort (aversion to effort) increase rather slowly with effort (individuals who are more efficient or more tolerant to effort).

The organization's performance will also increase with the quality of the evaluation process. It is reasonable to suppose that the observations of $z$ and $v$ are subject to some error-in-variable phenomena. It will in general be possible to get a better quality of observation by spending more resources on evaluation. To determine the factors behind the determination of the efficient level of the budget earmarked to the evaluation task, let us suppose that the variance $\operatorname{Var}(e+\varepsilon+\gamma v)$ is a decreasing function of the budget $M$ spent on evaluation (or the size of the random sample of observation units). One can assume that the evaluation process is valuable (it reduces the variance) but subject to decreasing returns (the reduction is less and less important as the evaluation budget increases), that is $\frac{\partial \operatorname{Var}(\varepsilon+\gamma v)}{\partial M}<0$ and $\frac{\partial^{2} \operatorname{Var}(\varepsilon+\gamma v)}{\partial M^{2}}>0$. We can characterize the efficient budget as the budget that maximizes the profitability of the firm given by (22), that is, using the envelop theorem,

$$
\frac{\partial(22)}{\partial \operatorname{Var}(\varepsilon+\gamma \nu)} \frac{\partial \operatorname{Var}(\varepsilon+\gamma v)}{\partial M}-1=-\frac{1}{2} r \beta^{2} \frac{\partial \operatorname{Var}(\varepsilon+\gamma \nu)}{\partial M}-1=0
$$

that is,

$$
-\frac{\partial \operatorname{Var}(\varepsilon+\gamma v)}{\partial M}=\frac{2}{r \beta^{2}}
$$




\section{\# 8- THE PRINCIPLE OF EFFICIENCY IN THE EVALUATION BUDGET}

The efficient budget level to be spent on evaluation (monitoring) is such that the marginal impact of an increase in the budget in reducing the variance of the evaluation error is inversely proportional to the individual's degree of risk aversion and the square of the intensity of incentives.

This principle suggests that the smaller the degree of risk aversion is, and the weaker the intensity of incentives is, then the larger the evaluation budget should be (because the more efficient it is) and conversely, the larger the risk aversion and the higher the intensity of incentives, the less the firm should spend on evaluation. From principles \#6, \#7 and \#8, we obtain:

\section{\# 9- THE PRINCIPLE OF INFORMATIVENESS}

Incentive compensation formulas perform better (are less costly) when they are based on performance measures that are affected more by the individual's chosen level of effort and less by random factors.

It is quite frequent that an individual in an organization will be asked to perform more than one task, each requiring some effort or attention from the individual. Suppose that the individual is asked to perform two tasks with effort levels $e_{1}$ and $e_{2}$, each being evaluated through specific indicator variables. Then the $C E W$ and the variance of the compensation are given by:

$$
\begin{aligned}
\operatorname{CEW}=\alpha+ & \beta_{1}\left(e_{1}+\bar{\varepsilon}_{1}+\gamma \bar{\nu}_{1}\right)+\beta_{2}\left(e_{2}+\bar{\varepsilon}_{2}+\gamma \bar{\nu}_{2}\right)-C\left(e_{1}+e_{2}\right)-\frac{1}{2} r \operatorname{Var}(W) \\
\operatorname{Var}(W)= & \operatorname{Var}\left(\beta_{1}\left(e_{1}+\bar{\varepsilon}_{1}+\gamma_{1} \bar{\nu}_{1}\right)+\beta_{2}\left(e_{2}+\bar{\varepsilon}_{2}+\gamma_{2} \bar{\nu}_{2}\right)\right. \\
= & \beta_{1}^{2}\left(\operatorname{Var}\left(\varepsilon_{1}\right)+\gamma_{1}^{2} \operatorname{Var}\left(v_{1}\right)+2 \operatorname{COV}\left(\varepsilon_{1}, v_{1}\right)\right) \\
& +\beta_{2}^{2}\left(\operatorname{Var}\left(\varepsilon_{2}\right)+\gamma_{2}{ }^{2} \operatorname{Var}\left(v_{2}\right)+2 \operatorname{COV}\left(\varepsilon_{2}, v_{2}\right)\right) \\
& +2 \beta_{1} \beta_{2}\left(\operatorname{COV}\left(\varepsilon_{1}, \varepsilon_{2}\right)+\gamma_{1} \operatorname{COV}\left(\varepsilon_{2}, v_{1}\right)+\gamma_{2} \operatorname{COV}\left(\varepsilon_{1}, v_{2}\right)\right. \\
& \left.+\gamma_{1} \gamma_{2} \operatorname{COV}\left(v_{1}, v_{2}\right)\right) .
\end{aligned}
$$

Hence,

$$
\frac{\partial C E W}{\partial e_{1}}=\beta_{1}-C^{\prime}\left(e_{1}+e_{2}\right)=0
$$




$$
\frac{\partial C E W}{\partial e_{2}}=\beta_{2}-C^{\prime}\left(e_{1}+e_{2}\right)=0
$$

\# 10- THE PRINCIPLE OF EQUAL COMPENSATION INTENSITY

If the allocation of time or effort between two different activities cannot be monitored by the head of the organisation, then she must set the intensities of incentives at the same level; otherwise, the activity with the lower marginal rate of return to the individual receives too little time or attention.

The above principles imply the following two principles:

\section{\# 11- THE PRINCIPLE OF DEFERRED COMPENSATION}

If the impact of one's effort is expected to occur in a later period or to last many periods, the incentive pay system and the incentive payments must be evaluated and defined over the same period.

\section{\# 12- THE PRINCIPLE OF GROUP COMPENSATION}

If the impact of one's effort cannot be separated from the efforts of other members of a group, then the incentive pay must be applied to the group as a whole, the sharing between the individuals being determined internally if the individuals can better assess from the inside the contribution of each member.

\section{THE IMPLEMENTATION OF THE TWELVE PRINCIPLES}

The general and specific interpretation and implementation of the above principles in concrete, generic and particular cases is a difficult task which requires some thinking and planning. The thinking and planning relates respectively to what should be the proper interpretation of the principles in concrete cases and to what strategy should be defined to design the compensation formula and to gather the data necessary to its implementation 
throughout the organization. It is not the purpose of this paper to translate the theoretical principles into a cookbook of recipes each corresponding to a specific case. But it is clear that unless the principles are well understood, there is no hope to design appropriate compensating formulas. Let us recap the essential lessons of the above.

The first principle, the principle of insurance, says that in general, incentive pay is not desirable. If there is no major problem of observation or information regarding the agent's effort or characteristics, a constant, given and fixed pay is better because it is less costly on average for the firm without reducing the well being of the worker or manager. Hence, in all cases where the principal can observe reasonably well the effort and characteristics of the individual, she should determine the tasks to be done and offer a level of pay sufficient to attract the individual (or the necessary number of individuals) but independent of the performance of the firm or organization. This is the case for a large majority of workers and managers. But there are cases where effort and characteristics are difficult to assess. In those cases, an incentive pay system must be considered and designed and implemented if the costs of running such a system are not too high. If they are, the firm should move away from it even if this means a lower performance level.

The second principle, the principle of rationality, says that any individual, worker or manager will choose his level of effort in raising the performance of the organization in reference to his own well being, whatever are the determinants of this well being. If effort is costly, one expects that the level of effort provided will be suboptimal if it cannot be determined directly (this requires perfect observation) by the firm or principal. When effort is costly, unobservable and hence chosen by the individual, it will be set at a relatively low level unless incentives are provided to favour a higher level. Of course, different individuals may choose different levels of effort, without incentive pay provisions, because they have different "utility functions", that is, different values and different intrinsic motivations. 
The third principle, the principle of certainty equivalence, says that there is always a fixed pay contract that the individual will consider equivalent to an incentive pay: the former means a lower pay on average for the individual, but more security or less risk in his compensation. Combined with the fifth principle, the principle of the risk premium, it sets up the basic incremental costs an incentive pay system typically represents. The compensation for the higher level of effort and for the risk the individual is facing under an incentive pay system must be properly calibrated to avoid both losing the individual if the participation constraint is not met and ending up with a lower than aimed for or desired effort level. As the fifth principle indicates, the risk premium to be paid to the individual increases with the individual's risk aversion and the intensity of incentives, and decreases with the quality of the information provided by the indicator variable directly related to the effort level (information of the first order) and by the indicator variable related to the blurring factors (information of the second order). It will therefore be important to invest in the quality of those information sources and their processing.

The fourth principle, the principle of dual performance measures, stipulates that different sources of information must be properly calibrated and weighted in order to make an optimal use of each source. In the current model, we have two types of information, one providing imperfect indicators of the level of effort exerted by the individual, the other providing indicators on the level of uncertainty of the first type. Information of different types must be blended in a proper fashion as characterized by the fifth principle, not simply juxtaposed.

The sixth principle, the principle of intensity of incentives, together with the seventh principle, the principle of optimized performance, say that an organization must determined the level of effort to be demanded, if necessary, from its members, workers or managers, and how much risk must be imposed on the individuals to achieve this level of (unobserved) effort. Intensity is positively related to desired effort: the larger the desired effort is, the higher the intensity of incentives should be, and therefore the costlier the incentive pay system will be. 
The eighth principle, the principle of the efficient evaluation budget, says that a firm must be ready to invest in indicators definition and measure if it implements an incentive pay system, the more so the more difficult it is to improve the reliability of the evaluation process (to reduce its variance), the larger the representative level of risk aversion is in the organization, and the higher is the intensity of incentives. As mentioned before, an incentive pay system is costly, both in terms of the average compensation (to take account of the risk premium) and in terms of the resources to spend on its administration and efficiency. One crucial objective of the evaluation budget is to increase the informativeness of the different types of indicators to be used to ascertain the effort level exerted. That is the object of the ninth principle, the principle of informativeness.

The eleventh principle, the principle of deferred compensation, says that the incentive payments must be done at the time the information on performance is obtained. It is in line with the methodology of the economic value added (EVA) developed by Stern Stewart, a management consulting firm. EVA considers the cost of capital of the firm in the performance evaluation: economic profits (net of taxes and the cost of capital) rather than accounting profits must be used to ascertain performance. Moreover, EVA may be negative in some periods (for instance in the early years of an investment project) and positive in others. The timing of economic profits is as important as their level.

Finally, the twelfth principle, the principle of group compensation, says that it might be better for the principal to provide incentive pay for a group rather than for an individual (the same principles will apply to the group) if there is more information within the group than for an outside observer, that is, if members of the group have more reliable information on each other contribution, while this information remains unverifiable for the outsiders.

A striking example of this twelfth principle is the agricultural crisis of 1959-1961 in continental China. It is a particularly dramatic example of the consequences that can follow the failure to recognize the impacts of implicit (group) incentives contained in some reforms that change the economic environment of individuals. 
Agricultural collectivization in China began around 1952 and was immediately a clear success: the agricultural production increased in an impressive way between 1952 and 1958. In contexts where information can be manipulated, production cooperatives can be extremely profitable if certain organizational requirements, mainly those that allow for the proper handling of coordination and motivation through adequate mechanisms, are met. It appears that the organizational structure of the Chinese agricultural cooperatives met these requirements in the first few years.

In 1959, the production of grain decreased by $15 \%$ and did not recover in 1960. Then, in 1961, grain production plummeted more than 30\% below the levels reached in 1958 . Why? Justin Yifu Lin (1990), ${ }^{8}$ an economist of the University of Beijing at that time, attributes most of the fall in production to a modification of the organization of the cooperatives. In that case, the modification significantly reduced the possibility of effective coordination and efficient incentives for effort and resulted in a famine that caused an estimated 30 million deaths! What had happened?

Following the success of the first cooperatives, the Chinese government decided in 19581959 to extend the collectivization project to the whole agricultural production. The number of cooperatives had grown to more than 735,000 in 1957 with $119,000,000$ households as members or an average of 160 households per cooperative. By the autumn of 1958, these cooperatives were gathered in 22,000 communities that covered almost the totality of the Chinese territory and gathering an average of 5,000 households. Before 1959, members of a cooperative had the option of withdrawing their labour or physical capital in order to join another cooperative project if they believed that the productivity or their share of the benefits was insufficient in the first cooperative.

Various organizational changes were brought up in 1958-59. The right of withdrawal was abolished to simplify the administration of the system. The mode of remuneration was

\footnotetext{
${ }^{8}$ J.Y. Lin (1990), "Collectivisation and China's agricultural crisis in 1959-61," Journal of Political Economy 98, 1228-52. See also J.Y. Lin and D.T. Yang (2000), "Food Availability, Entitlements and the Chinese Famine of 1959-61," The Economic Journal 110, 136-158.
} 
also changed from a redistribution of the benefits based on points of merit, to a system primarily based on the member's needs, independently of his productivity. The control and surveillance of the effort provided by each member was possible when there were 160 households in the cooperative, thanks to the mutual observation of the comrades. However, when a cooperative reached 5,000 households, this task became impossible. Withdrawing the right of the individual to leave a cooperative and join another made the threat from more productive members totally void.

Although there is no consensus on the specific effect of each one of these organizational changes, one could predict that the general effect of these changes on effort and productivity levels would be disastrous, hence the famine. Intentions were most likely good, but replacing competence and rationality with incompetence and ideology ended up causing 30 million deaths! China had to wait for the de-collectivization of the eighties to recover the productivity levels recorded before 1959 !

There is nothing magical with incentive pay packages. If they are poorly designed, they are likely to generate more harm than good: garbage in, garbage out. The National Commission on the causes of the financial and economic crisis in the United States writes in its January 2011 report: ${ }^{9}$ "Compensation systems - designed in an environment of cheap money, intense competition, and light regulation - too often rewarded the quick deal, the short-term gain - without proper considerations of long-term consequences. Often, those systems encouraged the big bet - where the payoff on the upside could be huge and the downside limited. This was the case up and down the line - from the corporate boardroom to the mortgage broker on the street."

Not all examples of a misunderstanding of the impacts of reforms affecting incentives lead to such catastrophic situations and crises.

\footnotetext{
${ }^{9}$ US Financial Crisis Inquiry Commission, The Financial Crisis Inquiry Report, US Government Printing Office, Washington, January 2011, 662 pages (ISBN 978-0-16-087727-8).
} 
Jensen and Murphy in their very influential (2004) report ${ }^{10}$ make 38 recommendations on remuneration schemes, broadly defined. They first embed the remuneration schemes into a broader corporate value and control system: "Companies should embrace enlightened value maximization/enlightened stakeholder theory in which 'creating firm value' is not one of many objectives, but the firm's sole or governing objective ... And this governing objective must be complemented by a statement of corporate vision and strategy that guides and motivates the organization in creating value. Properly understood enlightened value creation ... insists on long-term value creation as the firm's governing objective.”(R-1)

They discuss remuneration schemes at a considerably more detailed level but their recommendations are all in line with the twelve principles discussed here. One of their most important groups of recommendations deals with the independence of the Board's remuneration committee: "Remuneration committees must take full control of the remuneration process, policies, and practices"(R-10), "Firms should resolutely refuse as a matter of policy to pay the fees for the contracting agents negotiating for the CEO or other top-managers"(R-11), "Remuneration committees should seldom, if ever, use compensation consultants for executive remuneration purposes who are also used by the firm for actuarial or lower level employee remuneration assignments"(R-17).

Jensen and Murphy insist on taking a global remuneration viewpoint: "Managers should receive annual statements that clearly summarize in one place the changes in their wealth in the prior year from all sources of remuneration from the firm (including changes in the present value of future retirement and deferred compensation)"(R-21). In the spirit of (15), they call for "Design bonus plans with 'linear' pay-performance relations"(R-26). They write: "Better-designed pay-performance relations are linear over a broad range, with very high (or non-existent) caps, and "bonus banks" that allow bonuses to be negative as well as positive. Bonus banks can be created in a number of ways including,

\footnotetext{
${ }^{10}$ Michael C. Jensen and Kevin J. Murphy, Remuneration: Where we've been, how we got to here, what are the problems, and how to fix them, European Corporate Governance Institute and Harvard Business School, 2004.
} 
for example, paying a bonus out over three years, where the unpaid bonus is available to make up some or all of a negative bonus in the current year."

They insist also on keeping an eye on the risk borne by the worker or manager: "Use performance measures that reduce compensation risk while maintaining incentives"(R30) since that risk is costly for the firm as we have seen above. Regarding group compensation, they argue in favour of relying on it whenever there are substantial interdependencies in productivity between the actions of two or more people or groups: "Pay particular attention to the choice of group versus individual performance measures"(R$31) .^{11}$

Finally, Jensen and Murphy consider a broader principle than our (ninth) principle of informativeness: "Managers should be held accountable for factors that are beyond their control if they can control or affect the impact of those uncontrollable factors on performance"(R-35).

All these practical recommendations are compatible with the twelve principles develop here.

\section{CONCLUSION}

We began this inquiry by claiming that incentive or variable pay is in general not desirable for two main reasons. First, it is costly. It creates remuneration variability or risk for workers and managers who are typically risk averse. Hence, incentive pay systems will be more expensive for firms and organizations because of the need to compensate people to convince them to bear such risk. Second, an incentive compensation system is costly to run both in gathering and processing information and in

\footnotetext{
${ }^{11}$ Team work and the incentives problem that such arrangements raise and create have been the object of numerous contributions in economic theory. See among others Rasmussen, E., "Moral hazard in risk-averse teams," Rand Journal of Economics 18 (3), 428-435; and McAfee, P.R. and J. McMillan, "Optimal Contracts for Teams," International Economic Review 32 (3), 561-577.
} 
controlling the potential resentment effect when compensation falls below the mean level, a situation which will occur no less than half of the time.

There are different reasons to revisit the topic of incentive pay at this time. There is strong criticism of actual systems in the context of the recent financial crisis and economic recession, which allegedly stemmed in part from the structure of incentive pay systems in place in the financial sector. ${ }^{12}$ Moreover, there are clear misunderstandings of the basic issues related to the role and nature of incentive pay in general.

The bird's eye view taken here is quite abstract and general. Because of that, the principles are relevant and can be applied to most if not all cases of incentive pay systems. The twelve principles are more a (difficult) path to an efficient incentive pay system than a recipe to apply without scrutiny. Too much of the latter clogs the compensation schemes in private sector and public sector firms and organizations. The twelve principles could be used by a Board as a guide to understand how the incentive pay system of its firm has been designed and how the different components have been evaluated and (stress) tested. Indeed, as the popular maxims go: "unless you know what you are looking for, there is little hope to find it" and "if you don't know where you are going, you will probably end up somewhere else."

No doubt the application of the twelve principles as a road map in setting up an incentive pay system will raise many challenges. But at least, they show the way to go and the questions to ask. The evaluation of the parameters, variances and covariances pose

\footnotetext{
${ }^{12}$ The popular press is filled with stories of inadequate incentive pay systems, echoing earlier works such as Jensen and Murphy, op.cit. According the US Financial Crisis Inquiry Commission (FCIC), op.cit.: "Compensation structures were skewed all along the mortgage securitization chain, from people who originated mortgages to people on Wall Street who packaged them into securities. Regarding mortgage brokers, often the first link in the process, FDIC Chairman Sheila Bair told the FCIC that their 'standard compensation practice ... was based on the volume of loans originated rather than the performance and quality of the loans made.' She concluded, 'The crisis has shown that most financial institution compensation systems were not properly linked to risk management. Formula-driven compensation allows high short-term profits to be translated into generous bonus payments, without regard to any longer-term risks.' SEC Chairman Mary Schapiro told the FCIC, 'Many major financial institutions created asymmetric compensation packages that paid employees enormous sums for short-term success, even if these same decisions result in significant long-term losses or failure for investors and taxpayers."
} 
significant problems. But those challenges can be met and the implementation of the twelve principles adapted to specific cases through different methodologies depending on the data which exist or can be mined. Confronting the challenges and costs of an efficient incentive pay system, the firm or organization must evaluate if those challenges and costs can be borne in order to capture larger gains in productivity, profitability or more generally benefits. ${ }^{13}$

\footnotetext{
${ }^{13}$ E.P. Lazear ("Performance Pay and Productivity", NBER WP 5672, July 1996) have shown in a detailed case study that switching from hourly wages to piece rates allowed a large autoglass company to raise average productivity and to attract a more able work force. In fact, gains in productivity were "extremely large, amounting to anywhere from about $20 \%$ to $36 \%$ of output ... About half of the worker-specific increase in productivity is passed on to workers in the form of higher wages."
} 